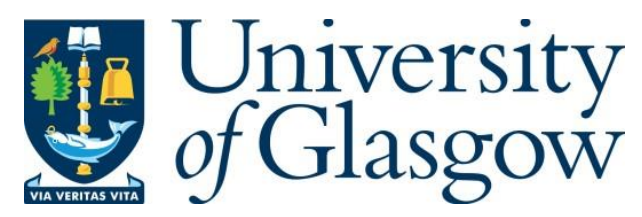

Waterston, T. and Wright, C. (2019) Sponsorship of paediatric associations by manufacturers of breastmilk substitutes. Lancet, 393(10172), pp. 622-623.

There may be differences between this version and the published version. You are advised to consult the publisher's version if you wish to cite from it.

http://eprints.gla.ac.uk/180814/

Deposited on: 22 November 2019

Enlighten - Research publications by members of the University of Glasgow http://eprints.gla.ac.uk 


\section{Sponsorship of paediatric associations by manufacturers of breastmilk substitutes}

Is it right that paediatric meetings should be sponsored by manufacturers of formula milk? There has recently been criticism of an international conference run by the UK Royal College of Paediatrics and Child Health (RCPCH) in Cairo, Egypt, in January, 2019, that initially announced sponsorship by manufacturers of breastmilk substitutes (BMS). ${ }^{1}$ On Jan 31,2019 , "in light of recent concerns raised by members", the RCPCH stated "we have made the decision to suspend future funding agreements with formula milk companies pending a College review of our relationships with them". ${ }^{2}$

Data from Public Health England ${ }^{3}$ show that only $44 \%$ of UK mothers breastfeed their infants at 6-8 weeks after birth and that there is a four-fold difference in breastfeeding rates between east London and Merseyside, despite evidence of the importance of breastfeeding for child and maternal health. ${ }^{4,5}$ Global trends similarly indicate that breastfeeding is not adequately protected, promoted, or supported. ${ }^{6}$ An important factor behind this trend could be the influence of manufacturers of BMS. A proposal at the 2018 World Health Assembly (WHA) to encourage breastfeeding and limit marketing of BMS was reportedly weakened after US pressure. ${ }^{7}$ According to an analysis by Bass for Maplight, ${ }^{8}$ three of the largest BMS manufacturers have spent an estimated US\$60.7 million lobbying US lawmakers and officials in the past decade.

BMS company profits are growing: the retail value of the global BMS market is estimated to reach about $\$ 62.5$ billion by $2020 .{ }^{9}$ Sales of BMS are growing rapidly in Asia, Eastern Europe, the Middle East, and Latin America. ${ }^{10}$ In 2015, sales of infant formula in China alone were predicted to reach US $\$ 27$ billion by $2017 .{ }^{10}$ The increasing baby food and BMS market supposedly exists because "parents are ready to spend on high-quality, expensive baby foods to ensure the well-being of their infants". ${ }^{11}$ BMS companies present themselves as making necessary products for parents who are unable or choose not to breastfeed, ${ }^{12}$ but their profits depend on maximising the number of babies not being breastfed. As Mead Johnson's former Chief Executive has said: "We have to wait for babies to be born that we can capture". ${ }^{13}$

Commercial pressure on governments from industry has been described as a "web of influence", ${ }^{14}$ working via interlocking connections between corporations, trade associations, policy bodies, and think tanks. These connections can also include health professionals. A 2014 private sector report on the "infant formula value chain" noted that "The major global multinationals put a large part of their selling effort into health practitioners, rather than retailers...as it works to sell product". ${ }^{15}$

It would be hoped that paediatricians would be working to resist commercial influence. Unfortunately, there have long been funding relationships between some paediatric organisations and BMS companies. ${ }^{16,17}$ This originally began as an attempt by paediatricians in the early 20th century to contain the use of breastmilk substitutes and enforce quality standards, ${ }^{18}$ but over the years it developed into a more friendly association and some paediatric associations accept funding from BMS companies to support conferences, training, or research-eg, the American Academy of Pediatrics ${ }^{19}$ and European Society for Pediatric Gastroenterology, Hepatology and Nutrition. ${ }^{20}$

BMS companies value this relationship with paediatricians ${ }^{21}$ as it enhances the credibility and sale of BMS products. However, those accepting funding have a conflict of interest ${ }^{22}$ and violate the guidance ${ }^{23}$ of the World Health Assembly that "health professional associations should not...accept equipment or services from companies that market foods for infants and young children, accept gifts or incentives from such companies" or "allow such companies to sponsor meetings of health professionals and scientific meetings". As Costello and colleagues ${ }^{24}$ stated "acceptance of funding or other incentives, 
however conditional, creates a sense of obligation and loyalty to the company in question". ${ }^{25}$ It could be argued that BMS funding encourages paediatricians and their organisations to overvalue the benefits of formula milk and be reluctant to acknowledge any adverse effects, as suggested by their own writing on the subject. ${ }^{17,26}$

Individual paediatricians lobby professional associations to divest themselves of BMS sponsorship and in some countries, such as India and South Africa, progress is being made, ${ }^{27,28}$ but in others the funding flow continues. ${ }^{29}$ In the UK, a nonbinding motion was passed at the RCPCH's annual general meeting in 2016 proposing a complete break from receiving income from BMS companies, ${ }^{30}$ but it was overturned in 2017 after a consultation of the membership which suggested that funding from "ethical" companies would be acceptable. ${ }^{31}$ However, recent events have persuaded the RCPCH to review this position. $^{2}$

Rather than each country fighting its own battle, the International Pediatric Association (IPA) could take a lead by issuing to its membership a strong statement of principle on curbing sponsorship from BMS manufacturers. ${ }^{32}$ With increasing visibility of breastfeeding at the political level, a more root and branch solution would be for nations to fully incorporate the International Code of Marketing of Breast-milk Substitutes and subsequent WHA resolutions into national legislation to outlaw such funding. ${ }^{33}$ This approach would have the wider advantage that it would also apply to other non-paediatric health professional organisations that accept BMS funding. ${ }^{29}$

\section{Tony Waterston *, Charlotte Wright ${ }^{*}$}

*International Society for Social Pediatrics, Newcastle Upon Tyne NE23AE, UK (TW); and +School Of Medicine, Dentistry and Nursing, University of Glasgow, Royal Hospital for Children, Glasgow, UK(CW)

tony.waterston@newcastle.ac.uk

TW is an adviser to Baby Milk Action. CW declares no competing interests.

1 Ratcliffe R. Leading UK child health body under fire over baby milk sponsorship. The Guardian, Jan 28, 2019. https://www.theguardian.com/global-development/2019/jan/28/british-child-health-experts-under-fire-overbaby-milk-sponsorship-royal-college-of-paediatrics (accessed Feb 1, 2019).

2 Royal College of Paediatrics and Child Health. RCPCH statement on future funding agreements with formula milk companies. Jan 31, 2019. https://www.rcpch.ac.uk/news-events/news/rcpch-statement-future-fundingagreements-formula-milk-companies (accessed Feb 1, 2019).

3 Public Health England. Breastfeeding at 6-8 weeks after birth: 2018-2019 quarterly data. October, 2018. https://www.gov.uk/government/statistics/breastfeeding-at-6-to-8-weeks-after-birth-2018-to-2019-quarterly-data (accessed Nov 2, 2018).

4 Victora CG, Bahl R, Barros AJD et al. Breastfeeding in the 21st century: epidemiology, mechanisms and lifelong effect. Lancet2016; 387: 475-90

5 Scientific Advisory Committee on Nutrition. Feeding in the first year of life. Public Health England, July 2018. https://www.gov.uk/government/publications/feeding-in-the-first-year-of-life-sacn-report (accessed Nov 2, 2018).

6 WHO. Tracking progress for breastfeeding policies and programmes: global breastfeeding scorecard 2017. Geneva: World Health Organization and UNICEF, 2017. http://www.who.int/nutrition/publications/infantfeeding/global-bfscorecard-2017/en/ (accessed Nov 2, 2018). 
7 Jacobs A. Opposition to breast-feeding resolution by US stuns world health officials. The New York Times, July 8, 2018. https://mobile.nytimes.com/2018/07/08/health/world-health-breastfeeding-ecuador-trump.html (accessed Nov 2, 2018).

8 Bass F. Infant formula makers sweetened mother's milk of politics with $\$ 60$ million in lobbying funds. Maplight, July 12, 2018. https://maplight.org/story/infant-formula-makers-sweetened-mothers-milk-of-politics-with-60-millionin-lobbying-funds/ (accessed Nov 2, 2018).

9 Statistica. Retail value of the babymilk formula market worldwide in 2010 and 2020. The Statistica Portal, 2018. https://www.statista.com/statistics/719436/global-market-size-baby-formula/ (accessed Nov 2, 2018).

10 Kent G. Global infant formula: monitoring and regulating the impacts to protect human health. Int Breastfeeding J 2015; 10: 6.

11 Research and Markets. Baby food and infant formula market: 2018-2023. Research and Markets. February, 2018. https://www.researchandmarkets.com/research/93kkn3/global_baby_food?w=5 (accessed Nov 2, 2018).

12 Nelsen A. Nestlé under fire for marketing claims on baby milk formulas. The GuardianFeb 1, 2018. https://www.theguardian.com/business/2018/feb/01/nestle-under-fire-for-marketing-claims-on-baby-milkformulas (accessed Nov 2, 2018).

13 Save the Children. Don't push it. London: Save the Children, 2018. https://www.savethechildren.net/sites/default/files/Don\%27t\%20Push\%20lt.pdf (accessed Nov 2, 2018).

14 Miller D, Harkins C, SchlogI M, Montague B. Impact of market forces on addictive substances and behaviours: the web of influence of addictive industries. Oxford: Oxford University Press, 2017.

15 Coriolis. Infant formula value chain. January, 2014. http://nzpecc.wisdomhealthprosperity.net/wpcontent/uploads/2015/12/Infant-Formula.pdf (accessed Nov 2, 2018).

16 Brady JP. Marketing breastmilk substitutes: problems and perils throughout the world. Arch Dis Childhood 2012; 97: 529-32.

17 Weaver LT. Relationships between paediatricians and infant formula milk companies. Arch Dis Child2006; 91: 38687.

18 Stevens EE, Patrick TE, Pickler R. A history of infant feeding. J Perinatal Educ 2009; 18: 32-39.

19 Mead Johnson \& Company, LLC. What is AAP Pediatric Care Online? 2019.

https://www.meadjohnson.com/pediatrics/us-en/professional-education/aap-pediatric-care-online (accessed Jan 2, 2019).

20 Danone Nutricia Research. Nutricia's Presence at ESPGHAN 2018. May 2, 2018. https://www.nutriciaresearch.com/nutricias-presence-at-espghan-2018/ (accessed Dec 13, 2018).

21 Wright CM, Waterston A. Relationships between paediatricians and infant formula milk companies. Arch Dis Child 2006; 91: 383-85.

22 Rodwin, Marc A. Attempts to redefine conflicts of interest. Account Res 2018; 25: 67-78. 
23 WHO. Sixty-ninth World Health Assembly. Guidance on ending the inappropriate promotion of foods for infants and young children. WHA69.7. May 13, 2016. http://apps.who.int/gb/ebwha/pdf_files/WHA69/A69_7Add1-en.pdf (accessed Nov 25, 2018).

24 Costello A, Branca F, Rollins N, Stahlhofer N, Grummer-Strawn L. Health professional associations and industry funding. Lancet 2017; 389: 597.

25 Clark D. Avoiding conflict of interest in the field of infant and young child feeding: better late than never. World Nutrition 2017; 8: 284-87.

26 Modi N, Greenough A, Viner R, Ellis J, Marsh M. Health professional associations and industry funding-reply from Modi et al. Lancet2017; 389: 1693-94.

27 Albersheim S, Couglin K. The relationship between paediatric practitioners and "industry". Paediatr Child Health 2017; 22: 357-59.

28 Bady JP, Srour L. India, Laos and South Africa reject sponsorship and gifts from formula countries. Africa Health Sci 2014; 14: 211-15.

29 First Steps Nutrition Trust. Websites and organisations that are funded by the formula milk industry. September, 2017. https://static1.squarespace.com/static/59f75004f09ca48694070f3b/t/5a5f9dec0d92977380f780ee/151621 5793060/Websites_and_organisations_short_Sep2017.pdf (accessed Nov 2, 2018).

30 Gullan A. Royal College told to stop taking money from infant formula milk firms. BMJ2016; 353: i.2459.

31 Thornton J. Paediatricians vote for college to continue accepting funds from infant formula companies. BMJ2016; 355: i5827.

32 International Paediatric Association. IPA guidelines for relations with industry. As approved by IPA EC May 2014. http://ipa-

world.org/uploadedbyfck/IPA\%20Guidelines\%20for\%20relationships\%20with\%20Industry_updated\%20May'14.pd $f$ (accessed Dec 17, 2018)

33 WHO. Marketing of breastmilk substitutes: national implementation of the International Code. Status report 2018. Geneva: World Health Organisation,2018. http://apps.who.int/iris/bitstream/handle/10665/272649/9789241565592-eng.pdf?ua=1 (accessed Nov 2, 2018). 